\title{
HAL - HAL POKOK DALAM PEMBUATAN SUATU KONTRAK
}

\author{
Oleh : \\ DR. Niru Anita Sinaga, SH, MH. \\ Dosen Tetap Fakultas Hukum Universitas Dirgantara Marsekal Suryadarma Jakarta. \\ Ketua LKBH Fakultas Hukum Unsurya \\ Email : (anita_s1naga@yahoo.com) \\ Dan \\ Nunuk Sulisrudatin, SH, M.Si \\ Dosen Tetap Fakultas Hukum Universitas Dirgantara Marsekal Suryadarma Jakarta. \\ Ketua Program Studi Ilmu Hukum Universitas Dirgantara Marsekal Suryadarma Jakarta \\ Email : (bununux@gmail.com)
}

\begin{abstract}
:
Today the business is growing, whether small, middle and top. Talking about the business can not be separated from what is called a contract. Almost every day we do a contract. It is therefore necessary understanding of matters relating to a contact, such as: What is a contract, the terms of validity of the contract, the principles of the contract, the object of the contract, the contract period, the contract form, the parties involved, the rights and obligations of the parties, the structure and anatomy of contracting, dispute settlement and expiration of the contract. The purpose of making the same contract with the purpose of the law in general, namely the creation of justice, order and legal certainty. However, in practice often led to problems. To overcome this, hence in making contracts or agreements let first understand about the contract, the consequences and the conditions to be met in the manufacture of the contract.
\end{abstract}

\section{Keywords: Contract and subject matter.}

\begin{abstract}
Abstrak:
Dewasa ini bisnis semakin berkembang, baik skala kecil, menengah dan atas. Berbicara tentang bisnis tidak terlepas dari apa yang disebut kontrak. Hampir setiap hari kita melakukan kontrak. Oleh karena itu perlu pemahaman tentang hal-hal yang berhubungan dengan suatu kontak, antara lain: Apa itu kontrak, syarat-syarat sahnya kontrak, asas-asas kontrak, objek kontrak, jangka waktu kontrak, bentuk kontrak, para pihak yang terlibat, hak dan kewajiban para pihak, struktur dan anatomi pembuatan kontrak, penyelesaian perselisihan dan berakhirnya kontrak. Tujuan pembuatan kontrak sama dengan tujuan hukum pada umunya yaitu terciptanya keadilan, ketertiban, dan kepastian hukum. Namun dalam pelaksanaannya sering menimbulkan permasalahan. Untuk mengatasinya, maka dalam pembuatan kontrak atau perjanjian hendaklah terlebih dahulu memahami tentang kontrak, akibatnya dan syarat yang harus dipenuhi dalam pembuatan kontrak.
\end{abstract}

\section{Kata kunci: Kontrak dan hal-hal pokok.}




\section{PENDAHULUAN}

Dewasa ini aktivitas bisnis berkembang begitu pesatnya dan terus merambah ke berbagai bidang, baik menyangkut barang maupun jasa. Perkembangan bisnis akan mendukung perkembangan ekonomi dan pembangunan. Kemajuan perekonomian suatu bangsa akan berdampak pada kesejahteraan masyarakat. Agar kesejahteraan tersebut dapat diwujudkan, salah satu caranya adalah dengan membuat peraturan yang mengatur semua kegiatan ekonomi bagi para pelaku bisnis tersebut. Peraturan yang mengatur terselenggaranya kegiatan dalam ekonomi atau bisnis disebut hukum bisnis.

Secara umum Hukum bisnis atau Business Law merupakan keseluruhan dari peraturan-peraturan hukum, baik yang tertulis maupun yang tidak tertulis, yang mengatur hak dan kewajiban yang timbul dari kontrak-kontrak atau perjanjianperjanjian maupun perikatan-perikatan yang terjadi dalam praktik bisnis.

Dalam pergaulan sehari-hari manusia tidak pernah lepas dari hukum, demikian juga halnya dalam bisnis. Hukum berperan untuk menjamin terselenggaranya persaingan yang sehat dalam bisnis. Pelaku bisnis harus memperhatikan rambu-rambu yang yang telah diatur oleh hukum tidak boleh menyimpang atau melaksanakan persaingan curang atau tidak sehat. Adanya hukum membuat suatu batasan dengan mempertimbangkan asas-asas dan norma-norma hidup.

Namun dalam menjalankan bisnis, tidak selamanya berjalan mulus. Kadang timbul perbedaan pendapat bahkan pertikaian diantara para pihak, untuk itu dibutuhkan adanya suatu aturan sebagai pedoman mulai saat hendak membuat kerjasama/bisnis, pada saat menjalankan dan juga sesudah pelaksanaan bisnis tersebut. Aturan yang akan dijadikan sebagai dasar yang mengikat bagi para pihak dibuat dalam bentuk kontrak atau perjanjian.

Secara umum kontrak atau perjanjian adalah: "Merupakan peristiwa dimana seorang berjanji kepada orang lain atau dimana dua orang itu saling berjanji untuk melaksanakan sesuatu hal, dari peristiwa ini timbullah suatu hubungan hukum antara pihak-pihak tersebut yang disebut perikatan"1

Perikatan adalah suatu hubungan hukum antara dua orang atau dua pihak berdasarkan mana pihak yang satu berhak menuntut sesuatu hal dari pihak yang lain dan pihak yang lainnya berkewajiban untuk memenuhi tuntutan itu". ${ }^{2}$

Hampir setiap hari kita melakukan apa yang dinamakan kontrak atau perjanjian, baik secara lisan maupun tertulis. Tanpa adanya kontrak, tidak mungkin hubungan bisnis dilakukan. Kontrak atau perjanjian bersifat mengikat. Dalam Pasal 1233 KUH Perdata disebutkan bahwa tiap-tiap perikatan dilahirkan dari perjanjian dan Undang - undang. Dengan demikian pemahaman tentang hal-hal yang berhubungan dengan suatu kontak, antara lain: Apa itu kontrak, syarat-syarat sahnya kontrak, asas-asas kontrak, objek kontrak, jangka waktu kontrak, bentuk kontrak, para pihak yang terlibat, hak dan kewajiban para pihak, struktur dan anatomi pembuatan kontrak, penyelesaian perselisihan dan berakhirnya kontrak.

\footnotetext{
${ }^{1}$ Sutarno, Aspek-Aspek Hukum Perkreditan pada Bank, Bandung: Alfabeta, 2003, hal. 73.

2 R.Subekti, Hukum Perjanjian, Jakarta: Intermasa, 2005, hal. 1.
} 
Tujuan pembuatan kontrak sama dengan tujuan hukum pada umunya yaitu terciptanya keadilan, ketertiban, dan kepastian hukum.

Kontrak atau perjanjian melahirkan perikatan, perikatan menimbulkan adanya hubungan hukum yang melahirkan hak dan kewajiban bagi masing-masing pihak.

Pasal 1320 KUHPerdata menentukan 4 syarat sahnya perjanjian, yaitu: ${ }^{3}$

1. Adanya kesepakatan kedua belah pihak.

2. Kecakapan untuk melakukan perbuatan hukum.

3. Adanya objek perjanjian

4. Adanya kausa yang halal.

Dalam suatu kontrak atau perjanjian selain harus memperhatikan syarat sahnya suatu kontrak atau perjanjian juga harus didasarkan pada beberapa asas atau prinsip umum yang terdapat pada hukum kontrak atau perjanjian, yaitu: Asas kebebasan berkontrak, asas konsensualisme, asas pacta sunt servanda, asas itikad baik asas kepribadian (personalitas). Juga prinsip lainnya yaitu: Asas kepercayaan, asas persamaan hukum, asas keseimbangan, asas kepastian hukum, asas moral, asas kepatutan, asas kebiasaan, dan asas perlindungan. Buku III KUH Perdata menganut system terbuka (open system), yang artinya bahwa para pihak bebas mengadakan kontrak dengan siapapun, menentukan syarat - syaratnya, pelaksanaannya, dan bentuk kontrak, baik berbentuk lisan maupun tertulis. Disamping itu, diperkenankan untuk membuat kontrak baik yang telah dikenal dalam KUH Perdata maupun di luar KUH Perdata. Namun dalam pelaksanaannya

${ }^{3}$ Salim H.S, Hukum Kontrak Teori dan Teknik Penyusunan Kontrak, Jakarta: Sinar Grafika, 2010, hal. 33-34. sering menimbulkan permasalahan. Untuk mengatasinya, maka dalam pembuatan kontrak atau perjanjian hendaklah berdasarkan pada syarat-syarat yang telah diatur dalam hukum kontrak.

Dapat disimpulkan bahwa tujuan pembuatan kontrak atau perjanjian dalam melakukan bisnis sama dengan tujuan hukum pada umunya yaitu terciptanya keadilan, ketertiban, dan kepastian hukum. Untuk mewujudkannya maka pelaku bisnis dalam menjalankan kegiatan bisnisnya harus memelihara pergaulan hidup secara tertib dan damai. Selain memiliki tujuan, hukum juga memiliki fungsi sebagai sarana dalam menyelesaikan sengketa, pencapaian keadilan lahir batin dan sebagai sarana pembaharuan masyarakat. Melalui hukum diharapkan tumbuh dan berkembangnya kesadaran masyarakat untuk hidup menuruti aturan yang ada, agar tercipta kedamaian dan kesejahteraan.

Didalam kontrak atau perjanjian terkandung makna "janji harus ditepati" atau "janji adalah hutang". Kontrak atau perjanjian merupakan suatu jembatan yang akan membawa para pihak untuk mewujudkan apa yang menjadi tujuan dari pembuatan kontrak atau perjanjian tersebut yaitu tercapainya perlindungan dan keadilan bagi para pihak.

Tanpa kontrak atau perjanjian orang tidak akan bersedia untuk terikat dan bergantung pada pernyataan pihak lain. Dengan kontrak atau perjanjian diharapkan masing-masing individu akan menepati janji dan melaksanakannya. ${ }^{4}$

Maka sudah seharusnya didalam kegiatan sehari-hari apabila membuat suatu kontrak

4 Reimon Wacks, Jurisprudence, London: Blackstones Press Limited, 1995, hal. 191. 
hendaklah memberikan perlindungan dan keadilan bagi para pihak. Berbicara tentang kontrak atau perjanjian tidak terlepas dari masalah keadilan. Dengan adanya kontrak atau perjanjian diharapkan pihak-pihak yang terlibat didalamnya dapat menjadikankan bisnis sesuai dengan kesepakatan-kesepakatan yang telah disetujui, melakukannya dengan itikad baik, dan sebagai dasar untuk menyelesaikan apabila timbul masalah dikemudian hari.

\section{RUMUSAN MASALAH}

Dari latar belakang yang telah diuraikan diatas dirumuskan 2 permasalahan sebagai berikut:

1. Hal apa saja yang harus diketahui dalam pembuatan suatu kontrak?

2. Bagaimana membuat suatu kontrak yang baik?

\section{PEMBAHASAN}

\section{A. Pengertian Kontrak dan Hukum Kontrak}

Salim H.S dalam bukunya Hukum Kontrak, mengemukakan bahwa kontrak berasal dari bahasa Inggris yaitu, contracts. Sedangkan dalam bahasa Belanda disebut dengan istilah overeenskomst (perjanjian).

BW menggunakan istilah kontrak dan perjanjian untuk pengertian yang sama. Hal ini dapat dilihat jelas dari judul Bab II Buku III BW yaitu: Tentang perikatan-perikatan yang dilahirkan dari kontrak atau perjanjian. Dari judul tersebut dapat diberikan makna bahwa kontrak dan perjanjian dimaknai dengan pengertian yang sama.
Subekti mengatakan: Perjanjian adalah suatu peristiwa di mana seorang berjanji kepada seorang lain atau di mana dua orang itu saling berjanji untuk melaksanakan suatu hal. Sedangkan perikatan adalah perhubungan hukum antara dua orang atau dua pihak, berdasarkan mana pihak yang satu berhak menuntut sesuatu hal dari pihak yang lain, dan pihak yang lain berkewajiban untuk memenuhi tuntutan tersebut.

Pasal 1313 KUHPerdata menyatakan: "Perjanjian adalah suatu perbuatan dengan mana satu orang atau lebih mengikatkan dirinya terhadap satu orang lain atau lebih". ${ }^{5}$

Black's Law Dictionary merumuskan kontrak sebagai berikut: "an agreement betwen two or more persons which creates an obligation, to do or not to do a particular thing". Diartikan kontrak adalah perjanjian antara 2 orang atau lebih yang menciptakan kewajiban untuk melakukan atau tidak melakukan suatu tindakan tertentu". ${ }^{6}$

Untuk mengatur semua yang berhubungan dengan kontrak dibutuhkan suatu hukum yang disebut hukum kontrak.

Charles L Knapp dan Nathan M Crystal, Hukum Kontrak: Mekanisme hukum dalam masyarakat untuk melindungi harapan-harapan yang timbul dalam pembuatan persetujuan demi perubahan masa yang akan

5 KUHPerdata, (Burgelijk Wetboek), diterjemahkan oleh R. Soebekti dan R. Tjitrisadibio, Jakarta: Pradya Paramita, cetakan 8, 1976, Pasal 1313, hal. 338.

${ }^{6}$ Henry Campbell Black, Black Law Dictionary, Sixth Edition, West Publishing Co, St. Paul Minn, 1990, hal. 322. 
datang yang bervariasi kinerja, seperti pengangkatan kekayaan (yang nyata maupun yang tidak nyata), kinerja pelayanan, dan pembayaran dengan uang.

Lawrence M. Friedman mengartikan hukum kontrak adalah: "Perangkat hukum yang hanya mengatur aspek tertentu dari pasar dan mengatur jenis perjanjian tertentu."

Salim H.S, mengatakan hukum kontrak adalah: "Keseluruhan dari dari kaidah-kaidah hukum yang mengatur hubungan hukum antara dua pihak atau lebih berdasarkan kata sepakat untuk menimbulkan akibat hukum".

Dari definisi diatas, dapat dikemukakan unsur-unsur yang tercantum dalam hukum perjanjian adalah: Adanya kaidah hukum, subjek hukum, adanya prestasi, kata sepakat, akibat hukum.

Menurut Munir Fuady, Hukum binis adalah suatu perangkat kaidah hukum (termasuk enforcement-nya) yang mengatur tentang tatacara pelaksanaan urusan atau kegiatan dagang, industri atau keuangan yang dihubungkan dengan produksi atau pertukaran barang atau jasa dengan menempatkan uang dari para entrepreneur dalam risiko tertentu dengan usaha tertentu dengan motif (dari entrepreneur tersebut) adalah untuk mendapatkan keuntungan. ${ }^{8}$

7 Lawrence M. Friedman, American Law An Introduction, penerjemah Whisnu Basuki, Jakarta: Tata Nusa, 2001, ha1. 196.

${ }^{8}$ Munir Fuady, Pengantar Hukum Kontrak (Menata Bisnis Moderndi Era Global), Edisi Revisi, Bandung: PT.Citra Aditya Bakti, 2005, hal. 2.
Berdasarkan rumusan pengertian perjanjian yang telah dikemukakan diatas dapat disimpulkan bahwa perjanjian itu terdiri dari: ${ }^{9}$

1. Ada pihak-pihak.

2. Ada persetujuan antara pihakpihak.

3. Ada prestasi yang akan di laksanakan.

4. Ada bentuk tertentu lisan atau tulisan.

5. Ada tujuan yang hendak di capai

\section{B. Beberapa Hal Penting Dalam Pembuatan Kontrak}

\section{Sistem Pengaturan Hukum} Kontrak

Sistem Pengaturan hukum kontrak adalah system terbuka (open system), artinya bahwa setiap orang bebas untuk mengadakan perjanjian, baik yang sudah diatur maupun yang belum diatur di dalam undangundang. Disimpulkan dari ketentuan yang tercantum dala pasal 1338 ayat (1) KUH Perdata, yang berbunyi "Semua perjanjian yang dibuat secara sah berlaku sebagai undang-undang bagi mereka yang membuatnya". Dan memberi kebebasan kepada para pihak untuk:

a. Membuat atau tidak membuat perjanjian.

b. Mengadakan perjanjian dengan siapapun.

c. Menentukan isi perjanjian, pelaksanaan, dan persyaratannya

9 Sudikno Mertokusumo, Mengenal Hukum: Suatu Pengantar, Yogyakarta: Liberty, 1999, hal. 82 . 
d. Menentukan bentuknya perjanjian, yaitu tertulis atau lisan.

\section{Asas Hukum Kontrak}

a. Asas Kebebasan Berkontrak. Kebebasan-kebebasan yang tidak bertentangan dengan peraturan perundangundangan. Pasal 133: Semua perjanjian yang dibuat secara sah berlaku sebagai undangundang bagi mereka yang membuatnya.

b. Asas Konsensualisme, Pasal 1320, 1338 KUHPerdata Kata sepakat para pihak

c. Asas Mengikatnya Suatu Perjanjian (Pacta Sunt Servanda). Pasal 1338 (1): Semua perjanjian yang dibuat secara sah berlaku sebagai undang-undang bagi mereka yang membuatnya Janji harus ditepati.

d. Asas Itikad Baik. Pasal 1338 (3): Bahwa perjanjian harus dilaksanakan dengan itikad baik.

e. Asas kepribadian (personalitas) Selain asasasas diatas Badan pembinaan hukum nasional Dep. Kehakiman 17-19 Desember 1985. Memberikan 8 asas hukum perikatan nasional: Asas Kepercayaan, Asas Persamaan Hukum, Asas Keseimbangan, Asas Kepastian Hukum, Asas Moral, Asas Kepatutan,_Asas Kebiasaan, Asas Perlindungan (Protection)
3. Syarat Sahnya Suatu Perjanjian Pasal $1320 \quad$ KUHPerdata menentukan empat syarat sahnya perjanjian, yaitu:

1. Adanya kesepakatan kedua belah pihak.

2. Kecakapan untuk melakukan perbuatan hukum.

3. Adanya objek perjanjian

Didalam berbagai literatur disebutkan bahwa yang menjadi objek perjanjian adalah prestasi (pokok perjanjian). Prestasi terdiri dari:

a. memberikan sesuatu

b. berbuat sesuatu dan

c. tidak berbuat sesuatu (Pasal1234 KUHPerdata).

4. Adanya causa yang halal.

Syarat pertama dan kedua disebut syarat subjektif karena menyangkut pihak-pihak yang mengadakan perjanjian. Syarat ketiga dan keempat disebut syarat objektif, karena menyangkut objek dari perjanjian. Apabila syarat pertama dan kedua tidak terpenuhi maka perjanjian dapat dibatalkan. Artinya salah satu pihak dapat mengajukan ke pengadilan untuk membatalkan perjanjian yang disepakati. Tetapi sepanjang para pihak tidak ada yang keberatan maka perjanjian itu adalah tetap dianggap sah. Jika syarat ketiga dan keempat tidak terpenuhi maka perjanjian itu batal demi hukum artinya, bahwa dari semula perjanjian dianggap tidak pernah terjadi. 
4. Bentuk dan Jenis-Jenis Kontrak Bentuk-Bentuk Kontrak

Bentuk Kontrak dapat dibedakan menjadi dua macam, yaitu tertulis dan lisan.

Berikut bentuk perjanjian tertulis:

\section{Jenis-Jenis Kontrak}

a. Kontrak Menurut Sumber Hukumnya.

b. Kontrak menurut namanya.

c. Kontrak menurut bentuknya.

d. Kontrak timbal balik.

e. Perjanjian cuma-cuma atau dengan alas hak yang membebani.

f. Perjanjian berdasarkan sifatnya.

g. Perjanjian dari aspek larangannya.

5. Istilah dan Ketentuan Yang Harus Diperhatikan Dalam Pembuatan Kontrak

a. Somasi. Somasi diatur dalam pasal 1238 dan 1243 KUHPer. Somasi adalah teguran dari si berpiutang (kreditur) kepada si berutang (debitur) agar dapat memenuhi prestasi sesuai dengan isi perjanjian yang telah disepakati antara keduanya. Ada tiga cara terjadinya somasi itu, yaitu:

1) Debitur melaksanakan prestasi yang keliru, misalnya kreditur menerima sekeranjang jambu seharusnya sekeranjang apel.

2) Debitur tidak memenuhi prestasi pada hari yang telah dijanjikan.

3) Prestasi yang dilakukan oleh debitur tidak lagi berguna bagi kreditur setelah lewat waktu yang diperjanjikan.

b. Prestasi. Prestasi merupakan hal yang harus dilaksanakan dalam suatu perikatan. Pemenuhan prestasi merupakan hakikat dari suatu perikatan.

c. Wanprestasi. Wanprestasi artinya tidak dipenuhinya prestasi atau kewajiban yang telah ditetapkan terhadap pihak-pihak tertentu didalam suatu perikatan, baik perikatan yang dilahirkan dari suatu perjanjian ataupun perikatan yang timbul kerna undangundang.

d. Ganti rugi. Ada dua sebab timbulnya ganti rugi, yaitu ganti rugi karena wanprestasi dan perbuatan melawan hukum. Ganti rugi karena wanprestai diatur dalam buku III KUHPer. Sedangkan ganti rugi karena perbuatan melawan hukum diatur dalam pasal 1365 KUHPer.

e. Keadaan memaksa. Keadaan memaksa adalah suatu keadaan dimana debitur tidak dapat melakukan prestasinya kepada kreditur, yang disebabkan adanya kejadian yang berada diluar kekuasaannya. Misalnya karena adanya gempa bumi, banjir bandang, lahar, dan lain-lain.

\section{f. Risiko}

\section{Hal-Hal Yang Harus Diperhatikan Dalam Pembuatan/ Penyusunan Kontrak}

Pada dasarnya kontrak yang dibuat oleh para pihak berlaku sebagai 
undang-undang bagi mereka yang membuatnya. Dengan demikian, kontrak yang dibuat oleh para pihak disamakan dengan undang-undang. Oleh karena itu, untuk membuat kontrak diperlukan ketelitian dan kecermatan dari para pihak, baim dari pihak kreditur maupun debitur, pihak investor maupun dari pihak negara yang bersangkutan.

Hal-hal yang diperhatikan oleh para pihak yang akan mengadakan dan membuat kontrak:

1. Kewenangan hukum para pihak.

2. Perpajakan.

3. Alas hak yang sah.

4. Masalah keagrariaan.

5. Pilihan hukum.

6. Penyelesaian sengketa.

7. Pengakhiran kontrak, dan

8. Bentuk perjanjian standar.

\section{Prinsip-prinsip dalam penyusunan kontrak}

\section{Prapenyusunan kontrak}

Sebelum kontrak disusun, ada empat hal yang harus diperhatikan oleh para pihak, antara lain: Indentifikasi para pihak, Penelitian awal aspek terkait, Pembuatan memorandum of understanding (MOU), Negosiasi

\section{Tahap penyusunan}

Pembuatan draf pertama, yang meliputi: Judul kontrak, Pembukaan (biasanya berisi tanggal pembuatan kontrak), Pihak-pihak dalam kontrak, Racital (penjelasan resmi/latar belakang terjadinya suatu kontrak), Isi kontrak (inti kontrak (yang dikehendaki, hak, dan kewajiban), Penutup (tata cara pengesahan suatu kontrak). Disini perlu: Saling menukar draf kontrak, Jika perlu

$$
\begin{aligned}
& \text { diadakan revisi, Dilakukan } \\
& \text { penyelesaian akhir, Penutup } \\
& \text { dengan penandatanganan kontrak } \\
& \text { oleh masing-masing pihak. }
\end{aligned}
$$

\section{Struktur dan anatomi kontrak}

a. Bagian pendahuluan

1) Subbagian pembuka

2) Subbagian pencantuman identitas para pihak (caption)

3) Subbagian penjelasan

b. Bagian isi

1) Klausula definisi

2) Klausula transaksi

3) Klausula spesifik

4) Klausula ketentuan umum

\section{c. Bagian penutup}

1) Subbagian kata penutup

2) Subbagian ruang penempatan tanda tangan

\section{Pasca penyusunan kontrak}

Apabila kontrak telah dibuat dan ditandatangani oleh para pihak, maka ada dua hal yang harus diperhatikan oleh para pihak, yaitu sebagai berikut:

\section{Bentuk-bentuk penyelesaian sengketa}

Pada dasarnya setiap kontrak (perjanjian) yang dibuat para pihak harus dapat dilaksanakan dengan sukarela atau iktikad baik, namun dalam kenyataannya kontrak yang dibuatnya seringkali dilanggar. Pola penyelesaian sengketa dapat dibagi menjadi dua macam, yaitu melalui pengadilan, dan alternative penyelesaian sengketa.

Penyelesaian melalui pengadilan adalah suatu pola penyelesaian sengketa yang terjadi antara pihak yang diselesaikan oleh pengadilan. Putusannya bersifat mengikat. Sedangkan penyelesaian sengeketa melalui alternative penyelesaian 
sengketa (ADR) adalah lembaga pemyelesaian sengkea atau beda pendapat melalui prosedur yang disepakati para pihak, yakni penyelesaian di luar pengadilan dengan cara konsultasi, negosiasi, mediasi, konsiliasi, atau penilaian ahli.

Bentuk-bentuk penyelesaian, antara lain:

\section{Litigasi}

Litigasi merupakan suatu proses gugatan, suatu sengketa diritualisasikan yang menggantikan sengketa sesungguhnya, yaitu para pihak dengan memberikan kepada seorang pengambil keputusan dua pilihan yang bertentangan.

\section{Arbitrase}

Arbitrase adalah penyelesaian sengketa perdata di luar peradilan umum yang berdasarkan pada perjanjian arbitrase yang dibuat secara tertulis oleh pihak yang bersengketa.

\section{Mediasi}

$\begin{array}{lrr}\text { Mediasi } & \text { adalah } & \text { metode } \\ \text { penyelesaian } & \text { masalah } & \text { yang }\end{array}$ dilakukan secara sukarela, rahasia, dan biasanya kooperatif, dan tidak ada unsur paksaan.

\section{Mediasi-arbitrase}

Salah satu variasi dari mediasi adalah suatu produser dimana sengketa pertama kali diselesaikan dengan mediasi dan berikutnya bilamana perlu terhadap isu-isu yang tidak terselesaikan dilakukan melalui arbitrase.

\section{Konsiliasi}

Isi konsiliasi adalah penyelesaian sengeketa kepada sebuah komisi dan keputusan yang dibuat oleh komisi tersebut tidak mengikat para pihak. Artinya bahwa para pihak dapat menyetujui atau menolak isi keputusan.

\section{Berakhirnya Perjanjian}

Hapusnya suatu perikatan diatur dalam Bab IV Buku III KUHPerdata Pasal 1381 KUHPerdata, yaitu: Pembayaran, penawaran tunai disertai dengan penitipan, pembaharuan hutang, perjumpaan hutang, percampuran hutang, pembebasan hutang, musnahnya benda yang terhutang, kebatalan atau pembatalan, berlakunya syarat batal, kadaluarsa atau lewat waktu.

Menurut R. Setiawan ada beberapa cara yang dapat mengakibatkan berakhirnya suatu perjanjian, yaitu: ${ }^{10}$

1. Ditentukan dalam perjanjian oleh para pihak

2. Suatu perjanjian berakhir pada saat yang telah ditentukan oleh para pihak

3. Para pihak atau undang-undang dapat menentukan bahwa dengan terjadinya peristiwa tertentu maka perjanjian akan hapus.

4. Tujuan telah tercapai.

5. Dengan perjanjian para pihak (herroeping).

\section{KESIMPULAN DAN SARAN}

\section{Kesimpulan}

1) Berbicara tentang bisnis tidak terlepas dari apa yang disebut kontrak. Hampir setiap hari kita melakukan kontrak. Oleh karena itu perlu pemahaman tentang hal-hal yang berhubungan dengan suatu kontak, antara lain: Apa itu kontrak, syarat-syarat sahnya kontrak, asas-asas kontrak, objek

${ }^{10}$ R. Setiawan, Pokok-pokok Hukum Perikatan, Bandung: Binacipta, 1978, hal. 24. 
kontrak, jangka waktu kontrak, bentuk kontrak, para pihak yang terlibat, hak dan kewajiban para pihak, struktur dan anatomi pembuatan kontrak, penyelesaian perselisihan dan berakhirnya kontrak. Tujuan pembuatan kontrak sama dengan tujuan hukum pada umunya yaitu terciptanya keadilan, ketertiban, dan kepastian hukum. Hal ini perlu agar dalam pelaksanaannya tidak menimbulkan permasalahan.

2) Dalam suatu kontrak atau perjanjian selain harus memperhatikan syarat sahnya suatu kontrak atau perjanjian juga harus didasarkan pada beberapa asas atau prinsip umum yang terdapat pada hukum kontrak atau perjanjian, yaitu: Asas kebebasan berkontrak, asas konsensualisme, asas pacta sunt servanda, asas itikad baik asas kepribadian (personalitas). Juga memperhatikan tentang: Prinsipprinsip dalam penyusunan kontrak mulai dari Prapenyusunan kontrak, Tahap penyusuna meliputi: Struktur dan anatomi kontrak, Pasca penyusunan kontrak, Bentuk-bentuk penyelesaian sengketa, Berakhirnya Perjanjian

\section{Saran}

1) Melihat pentingnya peranan kontrak dalam melaksanakan bisnis, maka dibutuhkan suatu aturan yang memadai dalam menyempurnakan aturan-aturan yang telah ada selama ini

2) Sebelum melakukan kontrak hendaklah terlebih dahulu mempersiapkan hal-hal yang akan dituangkan dalam klausul kontrak dan memahami cara membuat kontrak dengan baik
3) Apabila kurang memahami tentang bagaimana membuat kontrak yang baik, hendaklah bbertanya sama yang memahami karena akibat kontrak menimbulkan perikatan bagi para pihak.

\section{DAFTAR PUSTAKA}

\section{A. Buku}

Friedman, Lawrence Meir, American Law An Introduction, Terjemahan Wisnu Basuki, Jakarta: Tanusa., 2001.

Munir Fuady, Pengantar Hukum Kontrak (Menata Bisnis Moderndi Era Global), Edisi Revisi, Bandung: PT. Citra Aditya Bakti, 2005.

R. Setiawan, Pokok-pokok Hukum Perjanjian, Bandung: Bina Cipta. 1987

R. Subekti, Hukum Perjanjian, Jakarta: Intermasa, 2005.

Salim H.S, Hukum Kontrak Teori dan Teknik Penyusunan Kontrak, Jakarta: Sinar Grafika, 2010.

Sudikno Mertokusumo, Mengenal Hukum: Suatu Pengantar, Yogyakarta: Liberty, 1999.

Pihak Dalam Kontrak Kredit Bank di Indonesia, Jakarta: Institut Bankir Indonesia, 1993.

Sutarno, Aspek-Aspek Hukum Perkreditan pada Bank, Bandung: Alfabeta, 2003.

Wacks, Reimon, Jurisprudence, London: Blackstones Press Limited, 1995.

\section{B. Peraturan Perundang-undangan}

Kitab Undang-Undang Hukum Perdata (Burgelijk Wetboek), diterjemahkan oleh R. Soebekti dan R. Tjitrisadibio, Jakarta: Pradya Paramita, cetakan 8, 1976.

\section{Kamus / Ensiklopedia}

Campbell Black, Henry, Black Law Dictionary, Sixth Edition, West Publishing Co., St. Paul Minn, 1990. 